\title{
INTERNATIONAL
}

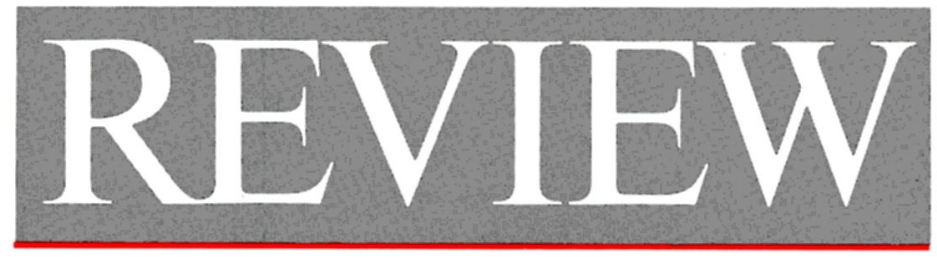

\section{OF THE RED CROSS}

Published every two months by the International Committee of the Red Cross for the International Red Cross and Red Crescent Movement 


\section{INTERNATIONAL COMMITTEE OF THE RED CROSS}

Mr. CORNELIO SOMMARUGA, Doctor of Laws of Zurich University, Doctor h.c. rer. pol. of Fribourg University (Switzerland), President (member since 1986)

Mrs. DENISE BINDSCHEDLER-ROBERT, Doctor of Laws, Honorary Professor at the Graduate Institute of International Studies, Geneva, Judge at the European Court of Human Rights, Vice-President (1967)

Mr. MAURICE AUBERT, Doctor of Laws, Vice-President (1979)

Mr. ULRICH MIDDENDORP, Doctor of Medicine, head of surgical department of the Cantonal Hospital, Winterthur (1973)

Mr. ALEXANDRE HAY, Honorary doctorates from the Universities of Geneva and St. Gallen, Lawyer, former Vice-President of the Governing Board of the Swiss National Bank, President from 1976 to $1987(1975)$

Mr. ATHOS GALLINO, Doctor h.c. of Zurich University, Doctor of Medicine, former mayor of Bellinzona (1977)

Mr. ROBERT KOHLER, Master of Economics (1977)

Mr. RUDOLF JÄCKLI, Doctor of Sciences (1979)

Mr. DIETRICH SCHINDLER, Doctor of Laws, Professor at the University of Zurich (1961-1973) (1980)

Mr. HANS HAUG, Doctor of Laws, Honorary Professor at the University of St. Gallen for Business Administration, Economics, Law and Social Sciences, former President of the Swiss Red Cross (1983)

Mr. PIERRE KELLER, Doctor of Philosophy in International Relations (Yale), Banker (1984)

Mr. RAYMOND R. PROBST, Doctor of Laws, former Swiss Ambassador, former Secretary of State at the Federal Department of Foreign Affairs, Berne (1984)

Mr. ODILO GUNTERN, Doctor of Laws, former member of the Swiss Council of States (1985)

Mr. ANDRÉ GHELFI, former Central Secretary and Vice-President of the Swiss Federation of Metal Workers (1985)

Mrs. RENÉE GUISAN, General Secretary of the International "Institut de la Vie", member of the Swiss Pro Senectute Foundation, member of the International Association for Volunteer Effort (1986)

Mr. ALAIN B. ROSSIER, Doctor of Medicine, former Professor for the rehabilitation of paraplegics at Harvard University, lecturer at the Medical Faculty of Geneva University, Professor of Paraplegia at Zurich University, former President of the International Medical Society of Paraplegia (1986)

Mrs. ANNE PETITPIERRE, Doctor of Laws, barrister, lecturer at Geneva Law Faculty (1987)

Mr. PAOLO BERNASCONI, Barrister, LL. L., lecturer in economic penal law at the Universities of St. Gallen and Zurich, former Public Prosecutor at Lugano, member of the Swiss Pro Juventute Foundation (1987)

Mrs. LISELOTTE KRAUS-GURNY, Doctor of Laws of Zurich University (1988)

Mrs. SUSY BRUSCHWEILER, nurse, Director of the Bois-Cerf Nursing School in Lausanne and professor at the College of Nursing in Aarau, President of the Swiss Association of Nursing School Directors (1988)

Mr. JACQUES FORSTER, Doctor of Economics, Director of the Institute of Development Studies in Geneva (1988)

Mr. PIERRE LANGUETIN, Master of Economics and Social Studies, Doctor h.c. of the University of Lausanne, former President of the Governing Board of the Swiss National Bank (1988)

Mr. JACQUES MOREILLON, Bachelor of Laws, Doctor of Political Science, Secretary General of the World Organization of the Scout Movement, former Director General at the ICRC (1988)

\section{EXECUTIVE BOARD}

Mr. CORNELIO SOMMARUGA, President

Mr. MAURICE AUBERT

Mr. ATHOS GALLINO

Mr. RUDOLF JÄCKLI

Mr. PIERRE KELLER

Mr. ANDRÉ GHELFI

Mrs. ANNE PETITPIERRE 


\section{INTERNATIONAL REVIEW OF THE RED CROSS}

SEPTEMBER-OCTOBER

No 272

\section{THE RED CROSS AND RED CRESCENT EMBLEMS}

Yves Sandoz: The red cross and red crescent emblems: what is at stake ............................ 405

François Bugnion: The red cross and red crescent emblems . . . . 408

Professor Habib Slim: Protection of the red cross and red crescent emblems and the repression of misuse ............ 420

Antoine Bouvier: Special aspects of the use of the red cross or red

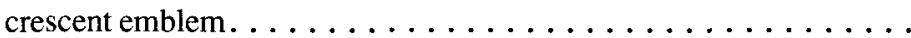

Michael A. Meyer: Protecting the emblems in peacetime: The experiences of the British Red Cross Society . . . . . . . . .

\section{4-1989}

Marking the 125th anniversary of the 22 August 1864 Geneva

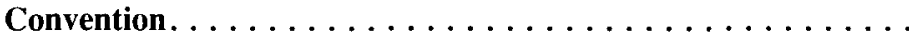

\section{INTERNATIONAL COMMITTEE OF THE RED CROSS}

President of the Swiss Confederation visits ICRC . . . . . . . 471

Federal Councillor Flavio Cotti visits ICRC $\ldots \ldots \ldots \ldots \ldots \ldots \quad 472$ 
News from Headquarters . . . . . . . . . . . . . . 472

EXTERNAL ACTIVITIES:

Africa - Latin America - Asia - Middle East . . . . . . . 474

IN THE RED CROSS AND RED CRESCENT WORLD

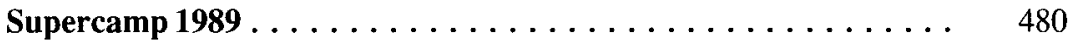

Death of Mr. Eustasio Villanueva Vadillo . . . . . . . . . . 482

\section{MISCELLANEOUS}

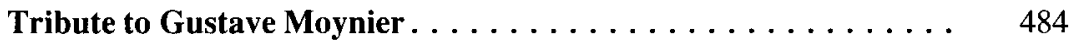

The Principality of Liechtenstein ratifies the Protocols. . . . . . . 488

The People's Democratic Republic of Algeria accedes to the Protocols . 489

The Grand Duchy of Luxembourg ratifies the Protocols. . . . . . . 490

\section{BOOKS AND REVIEWS}

Armed Conflict and the New Law: Aspects of the 1977 Geneva Protocols and the 1981 Weapons Convention (Michael A. Meyer,

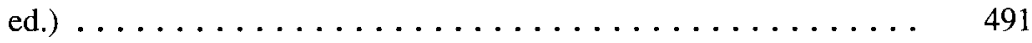

The Law of Naval Warfare (Natalino Ronzitti, ed.) . . . . . . . . 492

Necessità e proporzionalità nell'uso della forza militare in diritto internazionale (Necessity and proportionality in the use of military force under international law) (Gabriella Venturini) . . . . . . . 494

Addresses of National Red Cross and Red Crescent Societies . . . . . 496 